\title{
Effect of Soaking African Yam Bean Seeds in Unripe Plantain Peel Ash Solutions on the Nutrients, Anti-nutrients and Functional Properties of the Flour
}

\author{
Inyang Ufot Evanson*, Eyo Edima Atanguma \\ Department of Food Science and Technology, University of Uyo, Uyo, Akwa Ibom State, Nigeria
}

Email address:

inyang.ufot@yahoo.com (I. U. Evanson)

\section{To cite this article:}

Inyang Ufot Evanson, Eyo Edima Atanguma. Effect of Soaking African Yam Bean Seeds in Unripe Plantain Peel Ash Solutions on the Nutrients, Anti-nutrients and Functional Properties of the Flour. Journal of Food and Nutrition Sciences. Vol. 3, No. 4, 2015, pp. $147-151$. doi: $10.11648 /$ j.jfns.20150304.12

\begin{abstract}
The dark brown coloured variety of African yam bean seeds (Sphenostylis stenocarpa) were soaked in distilled water (control) and in 1,2,3,4 and 5\% solutions of unripe plantain peel ash $(1: 3 \mathrm{w} / \mathrm{v})$ for $15 \mathrm{~h}$ at room temperature $\left(27 \pm^{0} \mathrm{C}\right)$, decorticated and processed into flours. The effects of soaking the seeds in different concentrations of the ash solution on proximate, mineral and anti-nutrient composition as well as on the functional properties of the flours were investigated. Result showed that the treatments had varying effects on the parameters evaluated. Flours prepared from seeds that were soaked in ash solutions had significantly $(\mathrm{p}<0.05)$ higher protein, ash and crude fibre and significantly $(\mathrm{p}<0.05)$ lower carbohydrate and energy value than the values found in the flour from seeds that were soaked in water. Flours prepared from ash solutions soaked seeds had significantly $(\mathrm{p}<0.05)$ higher $\mathrm{K}, \mathrm{Ca}, \mathrm{Na}, \mathrm{Mg}, \mathrm{Fe}$ and $\mathrm{Zn}$ than the values found in the flour from seeds that were soaked in water. The mineral contents in the flours increased with increase in the levels of ash in the soaked solutions. On the other hand, the hydrogen cyanide, tannin, oxalate and phytate levels in the flours from ash solutions soaked seeds were significantly $(p<0.05)$ lower than their values in the flour from seeds that were soaked in water. The reductive effect of the antinutrients increased with increase in the levels of ash in the solutions used to soak the seeds. Flours from ash solutions soaked seeds had significantly $(\mathrm{p}<0.05)$ higher oil absorption capacity, marginally $(\mathrm{p}>0.05)$ higher swelling index and marginally $(p>0.05)$ lower water absorption capacity and bulk density than the flour from seeds that were soaked in water. It is evident from the study that soaking African yam bean seeds in unripe plantain peel ash solutions has beneficial effects as the flours prepared from the soaked seeds had higher levels of protein and mineral elements, lower levels of anti-nutrients and the functional properties were not impaired when compared with flour from seeds that were soaked in water.
\end{abstract}

Keywords: African Yam Bean, Anti-nutrients, Functional Properties, Nutrients, Unripe Plantain Peel Ash Solution

\section{Introduction}

The African yam bean (Sphenostylis stenocarpa) is a relatively unpopular and underutilized legume that is cultivated in the tropical rain forest and sub-tropical areas of the world [1]. It belongs to the family leguminosae. In Nigeria, African yam bean is cultivated by subsistent farmers for its seeds although there are reports about the use of tubers as food [2, 3, 4]. The bean is called "nsama" in Efik and Ibibio local dialects of Nigeria. The ripe pods vary between 120 and $130 \mathrm{~mm}$ in length and contain 10 to 30 seeds [3]. The smooth hard testa varies in seed size and colour. The colour of the testa varies from whitish and umarked to various shades of brown, black, grey with speckling or marbling [1].
The seed is a very significant substitute for cowpea (Vigna unguiculata) in the rainforest belt of Nigeria.

Nutritionally, the seeds have high protein content ranging from $15.8 \%$ to $34.7 \%$ [5] and a fairly good source of amino acids $[1,3,4]$. Amino acid analysis indicated that lysine and methionine levels in the seed protein are equal to or better than those of soybeans [5]. The high level of lysine in the seed implies that it can be used to supplement cereal proteins that are deficient in this essential amino acid. The seeds are also rich in mineral elements such as potassium, calcium, phosphorus, magnesium, iron and zinc but low in sodium and copper contents $[1,5]$. The excellent nutritive composition of the seed notwithstanding, their potentials in food application are yet to be fully investigated and exploited. The possession 
of objectionable beany flavour and odour, hard-to-cook phenomenon and the present of anti-nutritional factors are among the factors that presumably hampered their potential application in food systems [2].

The preparation of many Nigerian indigenous foods from grains and legumes involve soaking. Hotz and Gibson [6] noted that soaking is a household art. In order to tackle the problems associated with the African yam bean seed utilization, the seeds are usually soaked in water for $6-24$ hours $(7,8)$ or other solutions such as potash and sodium chloride [9] , sodium metabisulphite and trona [2]. Soaking of African yam bean seeds in water and salt solutions helps to soften the testa and dissolves the binding gum between the testa and cotyledon thereby facilitating dehulling and wet milling processes during paste production. It hastens cooking process, helps to leach out colouring matter, reduce antinutrients and substances that impart beany flavour in legumes [2]. Mubarak [10] reported that soaking mung bean seed prior to cooking reduced the concentration of toxic factors and flatulence including sugars (starchyose and raffinose) and gave a softer final texture to the cooked beans. The adverse effect of soaking is that it leads to leaching of some essential nutrients in the seed and the quality as well as functional properties of the seed may be affected [11, 12]. Traditionally, aqueous extract of unripe plantain peel ash is used in some rural communities in Akwa Ibom State, Nigeria to debitter Lasianthera africana leaf. The present study was aimed at investigating the effect of soaking African yam bean seeds in different concentrations of unripe plantain peel ash solution on the nutrients, anti-nutrients and functional properties of the flour.

\section{Materials and Methods}

The dark brown coloured variety of African yam beans (Sphenostylis stenocarpa) was used for this study. The pods were purchased from a market in Ikot Ekpene, Akwa Ibom State, Nigeria. The pods were manually split open and the seeds removed. Immature and infected seeds were sorted out and the good seeds shared into six equal portions of $1 \mathrm{~kg}$ each Portion 1 which served as the control sample was soaked in distilled water $(1: 3 \mathrm{w} / \mathrm{v})$ while portions $2,3,4,5$ and 6 were respectively soaked in $1 \%, 2 \%, 3 \%, 4 \%$ and $5 \%$ solutions of unripe plantain peel ash $(1: 3 \mathrm{w} / \mathrm{v})$ at room temperature $(27 \pm$ $2^{0} \mathrm{C}$ ) for $15 \mathrm{~h}$. The soaked solutions were drained off and the seeds washed with potable water. While washing, the seeds were rubbed in between the palms to decorticate them. Each portion of the decorticated seeds was separately dried in a conventional air oven (model P.P.22 US Genlab, England) at $60^{\circ} \mathrm{C}$ for $36 \mathrm{~h}$, winnowed to remove the chaff, milled, sieved to pass through $75 \mathrm{~mm}$ mesh screen, packaged in plastic container, labeled and stored at $4^{0} \mathrm{C}$ for various determinations.

\section{Methods of Analysis}

Crude protein, fat, ash and crude fibre were determined following the methods described in AOAC [13]. Carbohydrate was calculated by difference [14]. Mineral elements $(\mathrm{K}, \mathrm{Na}, \mathrm{Ca}, \mathrm{Mg}, \mathrm{Fe}$ and $\mathrm{Zn}$ ) were determined using atomic absorption spectrophotometer (UNICAM, Model 939, UK) as described in AOAC [13]. Hydrogen cyanide (HCN), tannin and oxalate were determined by AOAC [13] methods. Phytate determination was by Oberleas [15] method. Water absorption, oil absorption and swelling capacities were determined following the methods described by Abbey and Ibeh [16]. Bulk density was determined using the method described by Okezie and Bello [17].

\section{Statistical Analysis}

Data obtained were subjected to one way Analysis of Variance (ANOVA) using SPSS version 18 statistical package (SPSS, Inc., USA) to determine variation between treatments. Means of data generated were separated using Duncans Multiple Range Test (DMRT) Results were expressed as means \pm SD (Standard deviation) of triplicate determinations. Significant variation was accepted at $\mathrm{p}<0.05$.

\section{Results and Discussion}

\subsection{Effect of Treatment on Proximate Composition}

Data in Table 1 shows the proximate composition of decorticated African yam bean flours prepared from seeds that were soaked in water (control) and in different concentrations of unripe plantain peel ash solution. The result shows that flours prepared from seeds that were soaked in different concentrations of unripe plantain peel ash solution had significantly $(p<0.05)$ higher levels of protein, ash and crude fibre contents than the values found in the flour prepared from seeds that were soaked in water. These parameters in the flours from ash solution soaked seeds increased consistently with increase in the level of ash in the soaked solution. The higher protein content in the flours prepared from ash solution soaked seeds relative to flour from seeds that were soaked in water could be due to possible formation of complexes between some minerals in the ash solution and the protein in the seed thereby reducing its solubility and rate of leaching into the soaked solution. Meyer (18) listed copper, nickel and iron as examples of metal ions that can form complexes with protein and reduce its solubility. Differences in concentration gradient between water and ash solution used for soaking the seeds could have contributed to the higher ash content in the flours from ash solution soaked seeds than the value found in the flour from seeds that were soaked in water. The significantly $(p<0.05)$ lower carbohydrate in the flours prepared from seeds that were soaked in ash solutions relative to the value found in the flour from seeds that were soaked in water is a reflection of higher losses of carbohydrate in ash solution soaked seeds than in the seeds that were soaked in water. Higher losses of carbohydrate in ash solutions soaked seeds than in seeds that were soaked in water could have contributed to the higher 
crude fibre content in the flours from ash solutions soaked seeds than the value found in the flour from seeds that were soaked in water due to concentration effect. The marginal $(p>0.05)$ variation in the fat content of the flours could be due to the fact that fat is not soluble in water and in the ash solution used for soaking the seeds. The caloric value of the flour from seeds that were soaked in water was significantly ( $p>0.05$ ) higher than the values for the flours that were prepared from ash solution soaked seeds. This could be attributed to the significantly $(\mathrm{p}<0.05)$ higher carbohydrate content in the flour from seeds that were soaked in water than in the flours from ash solution soaked seeds.

Table 1. Effect of soaking African yam been seeds in ash solution on the proximate composition of the flour (Dry matter basis).

\begin{tabular}{|c|c|c|c|c|c|c|}
\hline \multirow{2}{*}{ Parameter } & \multicolumn{6}{|c|}{ Ash Concentration (\%) } \\
\hline & 0.00 & 1.00 & 2.00 & 3.00 & 4.00 & 5.00 \\
\hline Protein $(\%)$ & $19.25^{\mathrm{d}} \pm 0.02$ & $21.39^{\mathrm{c}} \pm 0.01$ & $22.06^{\mathrm{b}} \pm 0.00$ & $22.09^{\mathrm{b}} \pm 0.01$ & $22.39 .^{\mathrm{a}} \pm 0.01$ & $22.68^{\mathrm{a}} \pm 0.03$ \\
\hline Fat $(\%)$ & $2.20^{\mathrm{a}} \pm 0.01$ & $2.18^{\mathrm{a}} \pm 0.00$ & $2.19^{\mathrm{a}} \pm 0.03$ & $2.16^{\mathrm{a}} \pm 0.01$ & $2.17^{\mathrm{a}} \pm 0.02$ & $2.17^{\mathrm{a}} \pm 0.00$ \\
\hline Ash (\%) & $2.07^{\mathrm{e}} \pm 0.05$ & $2.49^{\mathrm{d}} \pm 0.01$ & $2.77^{\mathrm{c}} \pm 0.04$ & $3.17^{\mathrm{b}} \pm 0.02$ & $3.19^{\mathrm{ab}} \pm 0.00$ & $3.22^{\mathrm{a}} \pm 0.03$ \\
\hline Crude fibre (\%) & $1.83^{\mathrm{b}} \pm 0.08$ & $2.11^{\mathrm{a}} \pm 0.05$ & $2.13^{\mathrm{a}} \pm 0.03$ & $2.13^{\mathrm{a}} \pm 0.03$ & $2.15^{\mathrm{a}} \pm 0.01$ & $2.16^{\mathrm{a}} \pm 0.11$ \\
\hline Carbohydrate (\%) & $74.65^{\mathrm{a}} \pm 0.14$ & $71.83^{\bar{b}} \pm 0.11$ & $70.85^{\mathrm{c}} \pm 0.09$ & $70.35^{\mathrm{c}} \pm 0.03$ & $70.10^{\bar{c}} \pm 0.08$ & $69.77^{\bar{c}} \pm 0.20$ \\
\hline $\begin{array}{l}\text { Caloric value } \\
\text { (Kcal) }\end{array}$ & $395.40^{\mathrm{a}} \pm 0.21$ & $392^{\mathrm{b}} .50 \pm 0.08$ & $391.35^{\mathrm{b}} \pm 0.13$ & $389.20^{\mathrm{c}} \pm 0.32$ & $389.49^{c} \pm 0.09$ & $389.33^{\mathrm{c}} \pm 0.13$ \\
\hline
\end{tabular}

Values are means \pm SD of triplicate determinations. Means on the same column with different superscripts differ significantly $(\mathrm{p}<0.05)$

\subsection{Effect of Treatment in Minerals}

Table 2 depicts that the concentrations of unripe plantain peel ash solution used for soaking the seeds affected the mineral content in the flours prepared from the soaked seeds. Flour prepared from the seeds that were soaked in water had lower levels of $\mathrm{K}, \mathrm{Ca}, \mathrm{Na}, \mathrm{Mg}, \mathrm{Zn}$ and $\mathrm{Fe}$ than the values found in the flours prepared from ash solution soaked seeds. Ani et al.[19] similarly reported that Lasianthera africana leaf blanched in different concentrations of unripe plantain peel ash solution retained higher levels of $\mathrm{K}, \mathrm{Ca}, \mathrm{Na}, \mathrm{Mg}, \mathrm{P}, \mathrm{Zn}$ and $\mathrm{Fe}$ than hot water blanched samples. Also, Ejoh et al. [20] reported that leafy vegetables blanched in $2.5 \%$ and $5.0 \%$ "kanwa" solution exhibited lower mineral losses than hot water blanched samples. The higher mineral contents in the flours prepared from ash solutions soaked seeds relative to the values found in the flour from seeds that were soaked in water could be due to the fact that the ash solution contained mineral elements which possibly affected the concentration gradient with resultant lower losses of minerals into the soaked solution than occurred in water. The mineral elements in the flours increased with increase in the level of unripe plantain peel ash in the solutions used for soaking the seeds. Similar observation was reported for Lasianthera africana leaf blanched in different concentrations of unripe plantain peel ash solution (19). The low sodium content in the flour suggests that it could be used in the formulation of sodium restricted diets.

Table 2. Effect of soaking African Yam, bean seed in ash solution on the mineral content in the flour (mg/100g).

\begin{tabular}{|c|c|c|c|c|c|c|}
\hline \multirow{2}{*}{ Minerals } & \multicolumn{6}{|c|}{ Ash Concentration (\%) } \\
\hline & 0.00 & 1.00 & 2.00 & 3.00 & 4.00 & 5.00 \\
\hline $\mathrm{K}$ & $72.01^{c}+1.12$ & $75.99^{\mathrm{b}}+0.80$ & $76.82^{b}+0.04$ & $78.05^{\mathrm{b}}+1.11$ & $78.61^{\mathrm{b}}+0.70$ & $90.60^{\mathrm{a}} \pm 1.02$ \\
\hline $\mathrm{Na}$ & $18.22^{\mathrm{c}}+0.09$ & $20.93^{\mathrm{b}}+1.10$ & $21.40^{\mathrm{b}}+0.50$ & $23.08^{\mathrm{a}}+0.26$ & $24.11^{\mathrm{a}}+0.30$ & $24.90^{\mathrm{a}+1.22}$ \\
\hline $\mathrm{Ca}$ & $66.14^{\mathrm{c}} \pm 0.31$ & $68.51^{\mathrm{b}} \pm 0.00$ & $68.98^{\mathrm{b}} \pm 0.22$ & $70.32^{\mathrm{a}} \pm 0.06$ & $70.57^{\mathrm{a}} \pm 0.67$ & $71.06^{\mathrm{a}} \pm 0.25$ \\
\hline $\mathrm{Mg}$ & $19.56^{\mathrm{c}}+0.51$ & $22.04^{\mathrm{b}}+0.06$ & $23.80^{\mathrm{b}}+0.11$ & $25.31^{\mathrm{a}} \pm 0.00$ & $25.97^{\mathrm{a}} \pm 0.22$ & $26.89^{\mathrm{a}} \pm 0.31$ \\
\hline $\mathrm{P}$ & $251.25^{\bar{c}}+120$ & $260.18^{\mathrm{b}}+0.90$ & $260^{\mathrm{b}} .88+0.31$ & $263.00^{\bar{b}}+1.30$ & $267^{\mathrm{a}} .41+0.11$ & $268.30^{\mathrm{a}} \pm 0.40$ \\
\hline $\mathrm{Fe}$ & $10.65^{\mathrm{c}} \pm 0.00$ & $12.73^{\mathrm{b}} \pm 1.30$ & $12.98^{\mathrm{b}} \pm 0.80$ & $13.56^{\mathrm{b}} \pm 1.00$ & $15.32^{\mathrm{a}} \pm 0.60$ & $15.92^{\mathrm{a}} \pm 1.20$ \\
\hline
\end{tabular}

Values are means \pm SD of triplicate determinations. Means on the same row with different superscripts differ significantly $(\mathrm{p}<0.05)$

\subsection{Effect of Treatment on Anti-nutrients}

Table 3 shows the effect of soaking African yam bean seed in different concentrations of unripe plantain peel ash solution on the levels of anti-nutrients in the flour. Flour prepared from the seeds that were soaked in water had significantly $(\mathrm{p}<0.05)$ higher $\mathrm{HCN}$, oxalate, tannin and phytate contents than the values found in the flours from ash solutions soaked seeds. The reductive effective of these antinutrients increased with increase in the level of ash in the soaked solution. Similar decreased in anti-nutrients with increase in the level of unripe plantain peel ash in the solution used for blanching Lasianthera africana leaf has been reported [19]. Adeboye and Babajide [21] also reported that leafy vegetables blanched in hot water contained higher anti-nutrients than those blanched in $1 \%$ potash solution. The presence of anti-nutrients and toxic substances in most plant foods including African yam bean limits the bioavailability of some essential dietary minerals such as calcium, magnesium, iron and zinc in foods [14, 22]. The lower oxalate and phytate contents in the flours prepared from ash solutions soaked seeds relative to the values found in the flour from seeds that were soaked in water could lead better bioavailability of essential elements like calcium, magnesium and zinc that usually form complexes with these element [22, 23]. Similarly, the lower tannin content in the flours prepared 
from ash solution soaked seeds than in the flour from seeds

of amino acids and iron contained in the flour. that were soaked in water could lead to better bioavailability

Table 3. Effect of soaking African Yam bean seed in ash solution on the anti-nutrient contents in the flour (mg/100g).

\begin{tabular}{lllll}
\hline Ash Concentration (\%) & HCN & Tannins & Oxalate & Phytate \\
\hline 0.00 & $1.98^{\mathrm{a}} \pm 0.04$ & $3.25^{\mathrm{a}} \pm 0.22$ & $8.16^{\mathrm{a}} \pm 0.00$ & $6.41^{\mathrm{a}} \pm 0.03$ \\
1.00 & $1.70^{\mathrm{b}} \pm 0.10$ & $2.43^{\mathrm{b}} \pm 0.06$ & $7.52^{\mathrm{b}} \pm 0.90$ & $5.75^{\mathrm{b}} \pm 0.08$ \\
2.00 & $1.61^{\mathrm{b}} \pm 0.08$ & $2.40^{\mathrm{b}} \pm 0.14$ & $7.31^{\mathrm{b}} \pm 1.12$ & $5.08^{\mathrm{b}} \pm 0.06$ \\
3.00 & $1.48^{\mathrm{c}}+0.00$ & $2.34^{\mathrm{b}} \pm 0.08$ & $6.84^{\mathrm{b}} \pm 1.21$ & $4.92^{\mathrm{b}} \pm 0.00$ \\
4.00 & $1.45^{\mathrm{C}} \pm 0.11$ & $2.29^{\mathrm{C}} \pm 0.03$ & $6.07^{\mathrm{C}} \pm 0.16$ & $4.63^{\mathrm{C}^{ \pm} \pm 0.04}$ \\
5.00 & $0.90^{\mathrm{d} \pm 0.06}$ & $2.05^{\mathrm{c}} \pm 0.09$ & $5.21^{\mathrm{d}} \pm 0.28$ & $4.09^{\mathrm{C}} \pm 0.11$ \\
\hline
\end{tabular}

Values are means $\underset{+}{\mathrm{SD}}$ of triplicate determinations. Means on the same column with different superscripts differ significantly $(\mathrm{p}<0.05)$

\subsection{Effect of Soaking on Functional Properties of the Flour}

Table 4 shows the effect of soaking African yam bean seeds in different concentrations of unripe plantain peel ash solution on some functional properties of the flour. The result revealed that soaking the seeds in water and in ash solutions had varying effects on the functional properties of the flour. All the flours exhibited very high water absorption capacities ranging from $7.60 \pm \mathrm{g} / \mathrm{g}$ for flour from seeds that were soaked in $5.00 \%$ ash solution to $8.20 \pm 0.30 \mathrm{~g} / \mathrm{g}$ for flour from seeds that were soaked in water. The values were however not significantly ( $p>0.05)$ different from each other although flours from seeds that were soaked in $2.00 \%$ to $5.00 \%$ ash solutions had marginally lower values. The high water absorption capacity of the flours could be attributed to loose structure of starch polymers in the flour [24]. The baking quality of flours had been associated with the water absorption capacity of the flour [25]. Dough making potentials are improved by the ability of the flour to absorb water [26]. The high water absorption capacity obtained in this study is a useful indication that the flour can be incorporated into aqueous formations especially those involving dough handling. Flours prepared from seeds that were soaked in ash solutions had significantly $(p<0.05)$ higher oil absorption capacity than flour from seeds that were soaked in water. The oil absorption capacity of the flour consistently increased with increased levels of ash in the soaking solutions. The increase ranged from $6.73 \pm 0.64 \mathrm{~g} / \mathrm{g}$ for flour from seeds that were soaked in $1.00 \%$ ash solution to $8.03 \pm 0.13 \mathrm{~g} / \mathrm{g}$ for flour from seeds that were soaked in $5.00 \%$ ash solution. This observation could be attributed to higher levels of protein with increase in the concentration of ash in the solutions used to soak the seeds (Table 1). Fat acts as flavour retainer and increases the palatability of food [27]. The swelling index of the flour prepared from ash solutions soaked seeds was marginally ( $p>0.05$ ) higher than the value for the flour from seeds that were soaked in water. Concentration of ash in the soaked solution had no significant $(\mathrm{p}>0.05)$ effect on the swelling index of the flour. Both water absorption and swelling capacities contribute to dough formation and stability while fat absorption capacity is an important factor that contributes to texture of bread [28]. High swelling index has been reported as part of the criteria for a good quality product [29]. Bulk density values ranged from 0.70 for flour from seeds that were soaked in $5.00 \%$ ash solution to $0.89 \mathrm{~g} / \mathrm{cm}^{3}$ for flour from seeds that were soaked in water. The bulk density decreased with increase in the concentration of ash in the solutions used to soak the seeds. This could be attributed to decrease in carbohydrate with increase in the concentration of ash in the soaked solutions. Bulk density is generally affected by the particle size and it has relevant application in packaging, transportation and raw material handling [28, 30]. Low bulk density as found in the flours prepared from ash solution soaked seeds is desirable in infant feeding [26] and will occupy more space if packed in a container.

Table 4. Effect of soaking African Yam bean seed in ash solution on the functional properties of the flour .

\begin{tabular}{llll}
\hline Ash Concentration $(\%)$ & WAC $(\mathbf{g} / \mathbf{g})$ & OAC $(\mathbf{g} / \mathbf{g})$ & Swelling Index $(\mathbf{m l} / \mathbf{g})$ \\
\hline 0.00 & $8.20^{\mathrm{a}} \pm 0.30$ & $6.40^{\mathrm{e}} \pm 0.13$ & $1.05^{\mathrm{a}} \pm 0.02$ \\
1.00 & $8.20^{\mathrm{a} \pm 0.00}$ & $6.73^{\mathrm{d}} \pm 0.64$ & $1.06^{\mathrm{a}} \pm 0.01$ \\
2.00 & $8.00^{\mathrm{a}} \pm 0.12$ & $6.75^{\mathrm{d}} \pm 0.40$ & $1.06^{\mathrm{a}} \pm 0.13$ \\
3.00 & $7.60^{\mathrm{a} \pm 0.05}$ & $7.18^{\mathrm{c}} \pm 0.15$ & $1.10^{\mathrm{a} \pm 0.04}$ \\
4.00 & $7.60^{\mathrm{a} \pm 0.00}$ & $7.63^{\mathrm{b}} \pm 0.61$ & $0.89^{\mathrm{a}} \pm 0.03$ \\
5.00 & $7.60^{\mathrm{a}} \pm 0.11$ & $8.03^{\mathrm{a}} \pm 0.13$ & $1.14^{\mathrm{a} \pm 0.13}$ \\
\hline
\end{tabular}

Values are means \pm SD of triplicate determinations. Means on the same column with different superscripts differ significantly $(\mathrm{p}<0.05)$

$\mathrm{WAC}=$ water absorption capacity; OAC $=$ oil absorption capacity.

\section{Conclusion}

The study demonstrated that soaking the seeds in different concentrations of unripe plantain peel ash solution had varying effects on the proximate composition, minerals elements, anti-nutrients and functional properties of the flours. The protein, crude fibre, mineral elements, oil absorption and swelling capacities of the flour increased with increase in the concentration of ash in the solution used to soak the seed while carbohydrate, anti-nutrients, water absorption capacity and bulk density were decreasing with increased levels of ash in the soaked solution. 


\section{References}

[1] E. A. Nwokolo. "The need to increase consumption of pulses in the developing world" in E. A. Nwokolo and J. S. Smart (ed.). Food and Feed from legumes and oil seeds. Chapman and Hall, London 1996. pp 3-11.

[2] N. J. Enwere. Food of plant origin: Afro Orbis publications Ltd., Nsukka, Nigeria 1998. pp.24-78

[3] D. F. Apata and A. D. Ologhobo. Some aspects of biochemistry and nutritive value of African yam bean seeds (Sphenostylis stenocarpa). Food Chem. 36:271-280, 1990.

[4] B. Adewale, A. Daniel and C. O. Aremu. The nutritional potentials and possibilities in African yam bean for Africans. Int. J. Agric. 3(1): 8-19, 2013

[5] D. O. Edem, C. I. Amugo and O. U. Eka. Chemical composition of yam beans (Sphenostylis stenocarpa) Trop. Sci. 30:59-63, 1990.

[6] C. Hotz and R. S. Gibson. Assessment of home base processing methods to reduce the phytate content and phytate/zinc molar ratio of white maize (zea mays) J. Agric. Food Chem. 49: 692 - 698, 2001.

[7] S. A. Odunfa and S. Adeyele. Microbiological changes during traditional production of ogi-baba. A West African fermented sorghum gruel. J. Cereal Sci. 3:173-180, 1985.

[8] H. N. Ene-obong and I. C. Obizoba. Effect of domestic processing on the cooking time, nutrients, antinutrients and invitro protein digestibility of African yam bean (Sphenostylis stenocarpa). Plant food Hum. Nutr. 49:43-52, 1996.

[9] H. O. Njoku, I. Eli and C. O. Ofunya. Effect of pre-treatment on cooking time of African yam bean (Sphenostylis stenocarpa). J. Food Sci. 54: 758-759, 1989.

[10] A. E. Muburak. Nutritional composition and anti-nutritional factors of mung bean seed (phaseolus aureus) as affected by some home traditional processes. J. Food Chem. 89(4): 489495, 2005.

[11] L. F. De-leon, L. G. Elias and R. Bressani. Effect of salt solution on the cooking time, nutritional and sensory characteristics of common beans. Food Res. Int. 131-136. 1992.

[12] A. A. Olufunmilola and O. A. Rauf. Effect of dehulling/soaking on the chemical, functional and antinutritional content of three varieties of beans. Nutri Food Sci. 41(2): 117-122, 2011.

[13] AOAC, Official methods of Analysis (17 $7^{\text {th }}$ edn) Association of Official Analytical Chemist, Washington D. C. USA, 2000.

[14] A. I. Ihekoronye and P. O. Ngoddy. Integrated Food Science and Technology for the Tropics. MacMillan Edu. Publishers, London, 1985, pp. 283-285.

[15] D. Oberleas. "Phylates" in F. Strong (ed.) Toxicants occurring naturally in Foods. National Academy of Science, Washington D. C. USA, 1973, pp. $363-371$.
[16] B. W. Abbey and G. O. Ibeh. Functional Properties of raw and heat processed cowpea (Vigna unguiculata) floor. J. Food Sci 53(6): 1775 - 1778, 1988.

[17] B. O. Okezie and A. B. Bello. Physico-chemical and functional properties of winged bean flour and isolate compared with soy isolate. J. Food Sci. 53(2): 450-454, 1988.

[18] K. H. Meyer. Food chemistry ( $3^{\text {rd }}$ edn). The AVI Publication company Inc. Westport, Connecticut, USA, 1978, pp. 118-146.

[19] J. C. Ani, U. E. Inyang and I. Udoidem. Effect of concentration of debittering agent on the mineral, vitamin and phytochemical contents of Lasianthera africana leafy vegetable. Afri. J. Food Sci. 9(4): 194-199, 2015.

[20] R. A. Ejoh, D. V. Nkonga, G. Innocent and M. S. Moses. Effect of the method of processing and preservation on some quality parameters of three non-conventional leafy vegetables. Pak. J. Nutr. 6(2): 128-133, 2007.

[21] A. S. Adeboye and J. M. Babajide. Effect of processing methods on anti-nutrients in selected leaf. Nig. Food J. 25(2): 77-87, 2007.

[22] A. A. Akindahunsi and S. O. Salawu Phytochemical screening of nutrient and some anti-nutrient composition of selected tropical green leafy vegetables. Afr. J. Biotech. 4(6): 497-501, 2005.

[23] M. B. Grosvernor and L. A. Smolin. Nutrition: From Science to Life. Harcourt College Publishers, New York, USA, 2002, pp. 288-371.

[24] F. Y. Oladipo and L, M. Nwokocha. Effect of Sida acuta and Carborous olitorius mucilages on the physico-chemcial properties of maize and sorghum starches. Asian J. Appl. Sci. 4:514-523, 2011.

[25] T. A. Shittu, A. Dixon, S. O. Awonorin, L. O. Sanni and B. Maziya-Dixon. Bread from composite cassava-wheat flour. 11: Effect of cassava genotype and nitrogen fertilizer on bread quality. Food Res. Inter. 41: 569-578, 2008.

[26] M. O. Iwe and O. O. Onadipe. Effect of extruded full fat soy flour into sweet potato flour on functional properties of the mixture. J. Sustain. Agric. Environ. 3(1): 109-117, 2001.

[27] M. O. Iwe and E. I. Egwuekwe. Production and evaluation of cookies from xanthosonia sagitolium and colocasia escuenta blends. Nig. Food J. 23(1): 145-153, 2010.

[28] A. A. Olapado and O. B. Oluwole. Bread making potential of composite flour of wheat-acha (Digitaria exilis staph) enriched with cowpea (Vigna unguiculata L. Walp) flour. Nig. Food J. 31(1): 6-12, 2013.

[29] S. C. Achinewhu, I. J. Baiben and J. O. Ijeoma. Physicochemical properties and certification of selected cassava cultivars in Rivers State. Plant Food Hum. Nutr. 52:133-140, 1998.

[30] A. A. Adebowale, L. O. Sanni and M. O. Onitilio. Chemical composition and pasting properties of tapioca grit from different cassava varieties and roasting methods. Afri. J. Food Sci 2: 77-82, 2008. 